\title{
INCREASING SENSITIVITY OF MCF-7/DOX CELLS TOWARDS DOXORUBICIN BY HESPERETIN THROUGH SUPPRESSION OF P-GLYCOPROTEIN EXPRESSION
}

\author{
Sarmoko ${ }^{1,2}$, Dyaningtyas Dewi Pamungkas Putri ${ }^{1}$, Ratna Asmah Susidarti ${ }^{1}$, \\ Agung Endro Nugroho ${ }^{1}$, Edy Meiyanto ${ }^{1 *}$
}

${ }^{1}$ Cancer Chemoprevention Research Center, Faculty of Pharmacy, Gadjah Mada University, Yogyakarta Sekip Utara 55281, Indonesia 2Depertment of Pharmacy, Faculty of Medicine and Health Sciences, Jenderal Soedirman University, Jl. Dr.Gumbreg, Medical Street 53122. Purwokerto,Indonesia

Submitted: 28-01-2013

Revised: 20-01-2014

Accepted: 05-03-2014

*corresponding author Edy Meiyanto

Email:

meiyan_e@ugm.ac.id

\begin{abstract}
Long-term use of doxorubicin causes cancer resistance due to overexpression of $\mathrm{P}$-glycoprotein ( $\mathrm{P}-\mathrm{gp})$, a protein that plays a role in cell drug efflux. The purpose of this study is to determine the action of hesperetin in increasing the cytotoxicity of doxorubicin on MCF-7 cancer cells resistant to doxorubicin (MCF7/DOX) through suppression of P-gp expression. Cytotoxic assay of single and combinational treatment of doxorubicin and hesperetin were performed by using MTT assay. Apoptosis evidence was examined by using double staining with acridine orange and ethidium bromide dyes, while Pgp expression was determined by using immunocytochemistry. Hesperetin reduced cell viability in dose dependent manner. Both MCF-7 ori and MCF-7/DOX cells gave different responses to hesperetin with the $\mathrm{IC}_{50}$ values of $>500 \mu \mathrm{M}$ and $267 \mu \mathrm{M}$, respectively. Combining treatment of hesperetin and doxorubicin to MCF-7/DOX cells at the dose of $95 \mu \mathrm{M}$ and $230 \mathrm{nM}$ increased apoptosis evidence and suppressed P-gp expression. These results suggest that hesperetin enhances the anticancer effect of doxorubicin to resistance MCF-7 cells through suppression of P-gp expression.
\end{abstract}

Key words: Breast cancer, doxorubicin, resistance, hesperetin, Pglycoprotein

\section{INTRODUCTION}

Drug resistance has become one of the problems that often arise in the cancer therapy, especially breast cancer (Wong, et al., 2006). Breast cancer is the top case of cancer occurring among women worldwide. In Indonesia, the amount of breast cancer patients is about $12.10 \%$, the second only to cervical cancer $(19.18 \%)$. The high mortality rate indicates that chemotherapy has not overcome cancer disease completely. Problems in the chemotherapy of breast cancer have become more complicated due to the emergence of breast cancer resistance to chemotherapeutic agents (Wong et al., 2006). Therefore, strategy and development of breast cancer treatment should be explored.

Breast cancer cells' resistance to chemotherapeutic agents is caused by various factors. But it predominantly occurs due to the increase of Akt activity and expression of multi drug resistance 1 (MDR1) gene, the gene encoding P-glycoprotein after administration of doxorubicin, since doxorubicin has the ability to induce the expression of MDR1 gene (Emami et al., 2005; Li et al., 2005). Another study conducted by Bansal et al. (2009) revealed that some chemotherapeutic agents also showed similar action. Paclitaxel and daunorubicin increased P-gp expression in various cells in vitro. Elevated P-gp expression induced by chemotherapeutic agents is one of the causes of the resistance cases to chemotherapy. Because of these problems, the development of breast cancer chemotherapy is directed to the combination of doxorubicin with other compounds (co-chemotherapy) that increase the effectiveness of doxorubicin.

One of the proteins that regulate cell proliferation and survival is NF- $x \mathrm{~B}$ (Wang et al., 2002). NF- $x \mathrm{~B}$ is a transcription factor playing an important role in regulating proliferation and survival genes. Many reports suggested that the activation of $\mathrm{NF}-x \mathrm{~B}$ have broad implications for cancer resistance to chemotherapeutic agents. One of the important role of this 
transcription factor in rising cells resistance is by inducing expression of P-glycoprotein ( $\mathrm{P}$ gp), an efflux protein highly expressed and localized in cell membranes (Gilmore, 2006). The expression of P-gp might be suppressed through abrogation of NF- $x \mathrm{~B}$ signaling pathway, e.g. by inhibiting IKK, a protein kinase that plays a role in $\mathrm{NF}-x \mathrm{~B}$ activation. Some of the flavonoid compounds that are able to inhibit protein kinases are citrus flavonoids. Hesperetin is an aglycon form of flavonoid, commonly found in citrus fruit peel and was reported to perform cytotoxic activity on several cancer cells (Meiyanto et al., 2012). Our previous study on hesperidin, the glycoside forms of hesperetin, showed cytotoxic activity on MCF-7 cells and performed a synergistic effect with doxorubicin (Hermawan et al., 2009). Another study revealed that hesperetin performed inhibitory effects on breast cancer resistance protein (BCRP)-expressed K562 cancer cells (Imai et al., 2004). Therefore, we expect that hesperitin may inhibit NF-kB activation leading to suppression of $\mathrm{P}$-gP expression.

This study is conducted to examine the cytotoxic effect of hesperetin on doxorubicinresistant $\mathrm{MCF}-7$ cells (MCF-7/DOX), together with its apoptosis evidence and P-gp expression. The results of this study are expected to be used as a reference for further research in order to explore hesperetin as an alternative for co-chemotherapeutic agent in breast cancer therapy.

\section{MATERIALS AND METHOD}

\section{Sample preparation and cell culture}

Samples used were hesperetin obtained from Sigma-Aldrich (Catalog Number H4125$1 G)$ and doxorubicin (Ebewe). The human breast carcinoma cell line MCF-7 orginal (ori) was obtained from Cancer Chemoprevention Research Center (CCRC), while doxorubicinresistant $\mathrm{MCF}-7$ cells (MCF-7/DOX) were generated by inducing MCF-7 ori with low concentration of doxorubicin that was then characterized to over-express Pgp (Putri, et al., 2012). The cells were then immanently cultured in DMEM supplemented with 10\% Fetal Bovine Serum (FBS) (Sigma-Aldrich, USA) at $37^{\circ} \mathrm{C}$ in $5 \% \mathrm{CO}_{2}$ atmosphere, $1 \%$ penicillin- streptomycin. Subcultures were obtained after treatment with $0.25 \%$ trypsin-EDTA (Gibco, Canada).

\section{Cell viability assay: 3-(4,5-dimethyl- thiazol-2-yl)-2,5-diphenyltetrazolium bromide (MTT) assay}

Exponentially growing cells were seeded on 96-well plates at $1 \times 10^{4}$ cells per well and incubated for $24 \mathrm{~h}$ before the addition of drugs. Stock solution of the test compounds was initially dissolved in DMSO and further diluted with medium. Following a $24 \mathrm{~h}$ incubation at $37^{\circ} \mathrm{C}, \quad 5 \% \quad \mathrm{CO}_{2}$ and $100 \mu \mathrm{L}$ of various concentration of test extracts were added in each well in triplicates and cells were then incubated for $24 \mathrm{~h}$ at $37^{\circ} \mathrm{C}$. After that, the medium was removed and $100 \mu \mathrm{L}$ of MTT reagent $(1 \mathrm{mg} / \mathrm{mL})$ in medium was added to each well. The plates were then incubated at $37^{\circ} \mathrm{C}$ for $4 \mathrm{~h}$. At the end of the incubation period, the supernatants were removed and $100 \mu \mathrm{L} 0.01 \mathrm{~N} \mathrm{HCl} \mathrm{SDS} \mathrm{solution} \mathrm{was} \mathrm{added} \mathrm{to}$ each well. After an overnight incubation at $37^{\circ} \mathrm{C}$, the metabolised MTT dissolved product was quantified by reading the absorbance at $595 \mathrm{~nm}$ using an ELISA reader (Biorad). Absorbance data were then calculated in order to get the number of viable cells for both control and treated cells. To determine cell viability, percent viability was calculated as [(absorbance of drug-treated cells)-(absorbance of medium)/ (absorbance of control (untreated) cells- absorbance of medium)] $\times$ $100 \%$. The $\mathrm{IC}_{50}$ values are defined as the drug concentrations required to reduce the absorbance by $50 \%$ of the control.

\section{Apoptosis assay}

MCF-7/DOX cells were grown on glass cover slips in tissue culture dishes (Flacon) and were allowed to attach for $24 \mathrm{~h}$ prior to the addition of drug. After the cells were incubated with the test drug for $24 \mathrm{~h}$, the cover slips were washed in phosphate-buffered saline and fixed in object glass. Treated cells were stained with acridine orange and $5 \mu \mathrm{L}$ of ethidium bromide and visualized by fluorescence microscope. Viable (normal, green nuclei) and apoptotic (condensed, red nuclei) cells were then examined. 


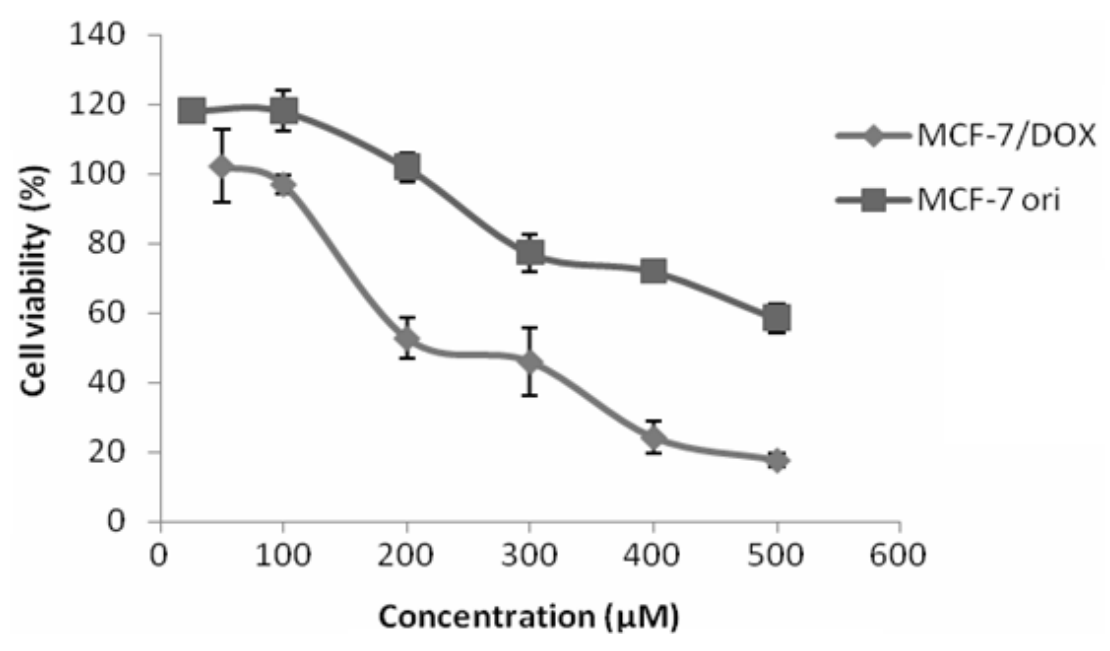

Figure 1. Hesperetin increased sensitivity of MCF/7Dox cells to doxorubicin. Cells were seeded in 96-well plates at a density of $10 \times 103$ cells per well for $24 \mathrm{~h}$, and then treated with various concentrations of hesperetin for $24 \mathrm{~h}$. Cell viability was then determined by adding MTT reagent and measuring the absorbance at $595 \mathrm{~nm}$ as described in 'Materials and methods'. IC50 was determined from a plot of percent cell viability from untreated control cells versus concentration. All results are expressed as mean \pm SD from three independent experiments

\section{Immunocytochemistry}

MCF-7 ori dan MCF-7/DOX breast cancer cells were cultured in a 24-well plates (Nalge Nunc International, Denmark) at the density of $2 \times 10^{5}$ cells per well, incubated for $24 \mathrm{~h}$. The cells were then treated with $0.5 \times \mathrm{IC}_{50}$ concentrations of hesperetin. After $24 \mathrm{~h}$, cells were plated in poly-L-lysin slide. Cells were fixed with methanol (pro analysis) for $5 \mathrm{~min}$, permeabilized for $5 \mathrm{~min}$ in PBS containing $0.2 \%$ Triton X-100, blocked in 2\% BSA for $1 \mathrm{~h}$, and stained with the monoclonal antibody P-gp $(1: 400)$ for $1 \mathrm{~h}$. They were then washed with PBS $3 \times 5 \mathrm{~min}$ and stained with bionylated secondary antibody for $1 \mathrm{~h}$. Incubation in HRPstreptavidin for $10 \mathrm{~min}$ was then followed by addition of $\mathrm{DAB}$ (3,3-diaminobenzidine) for $5 \mathrm{~min}$. Cells were then washed with aquadest, counter-stained with Harry's hematoxylin for 20 s, mounted on glass slides. The cells were examined by using a confocal microscope.

\section{Data analysis}

The data were analyzed using SPSS 15.0 software. Oneway Anova were employed to assess the statistical significance of difference between untreated and different treatment group. A statistically significant difference was considered to be present at $P<0.05$.

\section{RESULTS AND DISCUSSION Efect of hesperetin on cell viability of MCF-7/DOX}

Inhibitory effect of hesperetin on MCF7 ori and MCF-7/DOX cells was evaluated by using MTT assay. Exposure of hesperetin at various concentrations for $24 \mathrm{~h}$ showed cell growth inhibition in a concentration-dependent manner. Hesperetin on MCF-7 ori cells showed the cytotoxic effects with $\mathrm{IC}_{50}$ value greater than $500 \mu \mathrm{M}$, whereas the $\mathrm{IC}_{50}$ on MCF-7/DOX cells was $267 \mu \mathrm{M}$ (Figure 1). It was an interesting finding to be developed, because hesperetin was observed to be able to increase cell sensitivity on MCF-7/DOX against doxorubicin. Hesperetin, in combination with doxorubicin on MCF-7/DOX cells showed an increase in sensitivity of the cells. Therefore, we combined hesperetin and doxorubicin on MCF-7/DOX cells. The combination of hesperetin and doxorubicin showed increased cytotoxic effect, compared with doxorubicin 


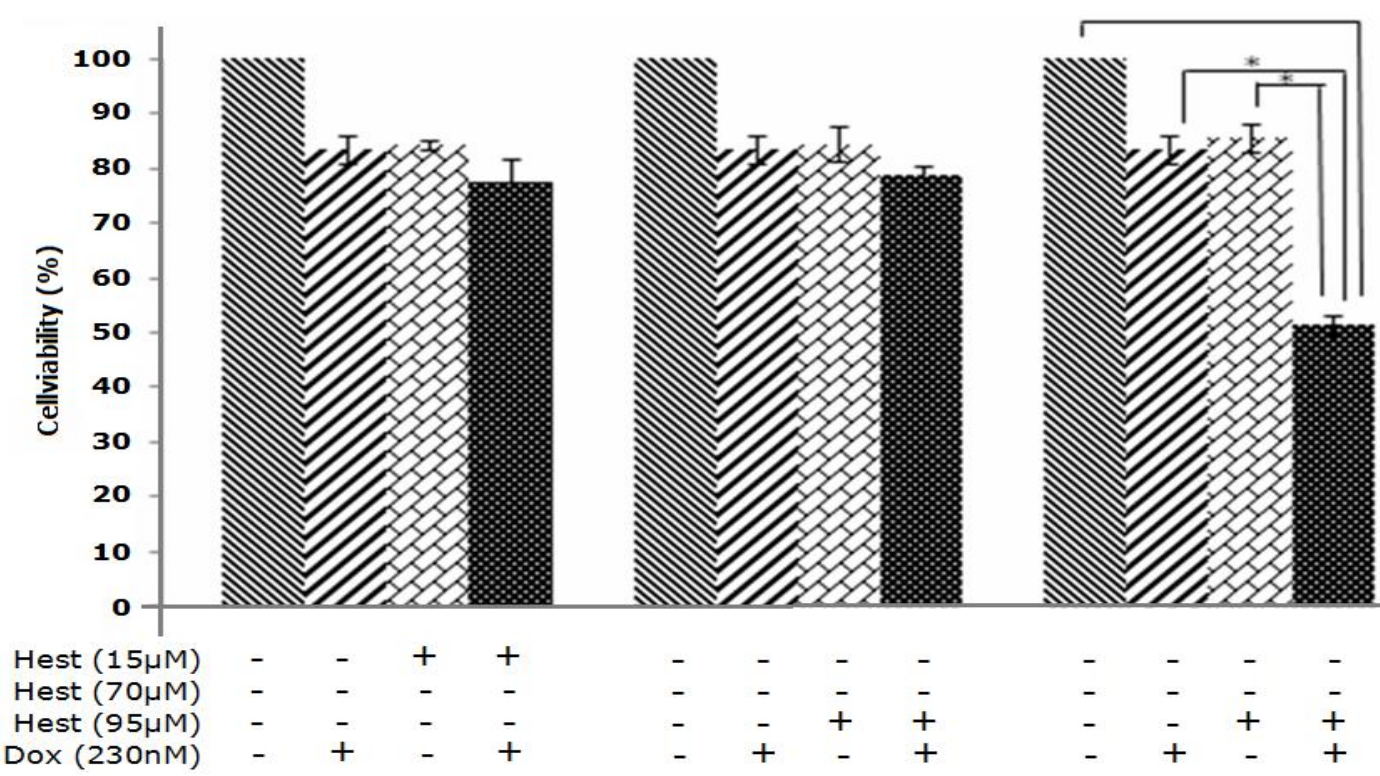

Figure 2. The effect of hesperetin and doxorubicin to MCF-7/DOX cells' viability. Cells were seeded in 96-well plates at a density of $10 \times 10^{3}$ cells with hesperetin concentration $15 \mu \mathrm{M}(\mathrm{A}), 70 \mu \mathrm{M}(\mathrm{B})$ and $95 \mu \mathrm{M}(\mathrm{C})$ and doxorubicin $(230 \mathrm{nM})$ towards MCF-7/DOX for 24h. After 24h, MTT reagent was added to calculate the absorbance which represents viable cells. Cell viability profile was shown from average \pm standard of error $(\mathrm{SE})$ of 3 experiments. $* P<0.05$

alone. At a fixed concentration of doxorubicin, higher concentration of hesperetin used showed more potent cytotoxic effect by the combination in cell viability compared with the single treatment. The optimum concentration was obtained in the combination of $230 \mathrm{nM}$ doxorubicin and $95 \mu \mathrm{M}$ hesperetin (Figure 2). The observation of apoptosis and P-gp expression was performed in this concentration.

\section{Apoptosis effect of doxorubicin and hesperetin on MCF-7/DOX cells}

To observe the effect of hesperetin alone and its combination to induce apoptosis on MCF-7/DOX cells, observation was conducted by using double staining method by using acridine orange-ethidium bromide (EB-AO). All control cells was in green colour, showing no cell death. Single treatment of hesperetin and doxorubicin solely resulted in green colour of most cells and orange colour of the rest. It indicates the loss of membrane permeability as an indication of cell death. Cells undergoing apoptosis showed an orange fluorescence in the cell nucleus fragmentation that became apoptotic bodies. Combinational treatment of doxorubicin and hesperetin gave more orange colour compared with the single treatment (Figure 3). This data suggest that the increase of effectiveness of doxorubicin's cytotoxicity on MCF-7/DOX cells is mediated by the induction of the apoptosis.

\section{Hesperetin and the effects of doxorubicin on the expression of P-gp}

To find the molecular mechanism of hesperetin in increasing the sensitivity of MCF7/DOX, we observed the expression of P-gp transporter. P-gp is a protein that is responsible for cancer cells' resistance to doxorubicin. The observation on P-gp expression by using imunocytochemistry showed excessive expression in cancer cells MCF-7/DOX with doxorubicin treatment. While the single hesperetin treatment showed no significant change in expression compared to untreated cells (Figure 4).

In this research, the biological activity of hesperetin in overcoming the resistance to chemotherapy drug was investigated. MTT results showed that hesperetin was able to 


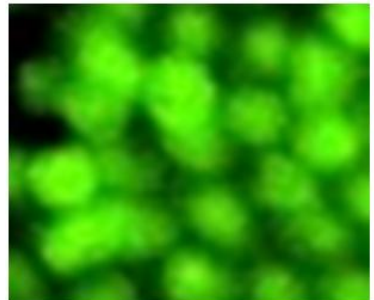

(A)

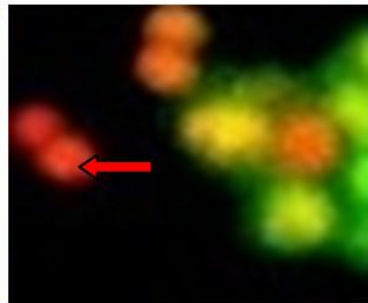

(B)

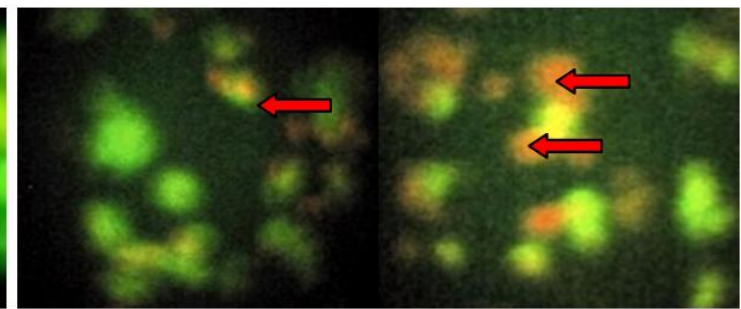

(C)

(D)

Figure 3. The apoptotic effect of doxorubicin, hesperetin and combination with doxorubicin on MCF-7/DOX cells. MCF-7/DOX cells were treated by doxorubicin, hesperetin, and their combination for $24 \mathrm{~h}$ and stained by etidium bromide-acridine orange. (A) Untreated cells; (B) cells treated with doxorubicin $230 \mathrm{nM},(C)$ hesperetin $95 \mu \mathrm{M}$, and (D) combination of hesperetin $95 \mu \mathrm{M}$ and doxorubicin 200nM. Viable cells give green fluorescence, apoptotic cells give orange fluorescence (pointed by red arrow). Examination of apoptosis was done by using fluorescent microscope with magnification $400 \mathrm{x}$. Hesperetin increased apoptosis induction of doxorubicin on MCF-7/DOX cells.

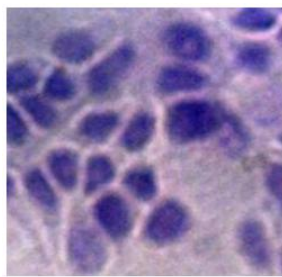

(A)

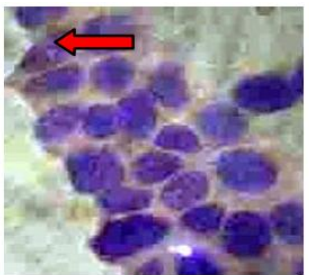

(B)

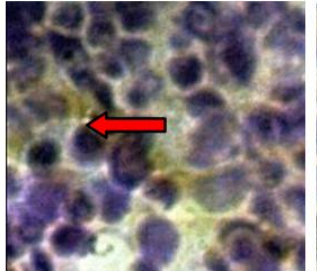

(C)

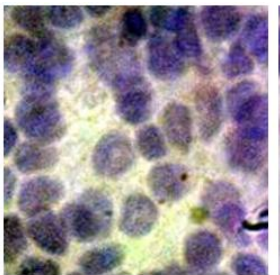

(D)

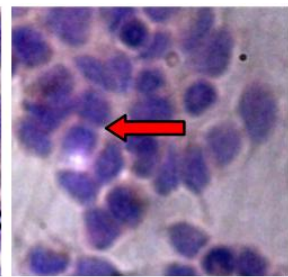

(E)

Figure 4. Effect of Hesperitin on P-gp Expression in MCF-7/DOX cells. MCF-7/DOX cells cultured in 24-well plates with density $1 \times 10^{5}$ cells per well on coverslip. (A) Control without antibody; (B) control with antibody; (C) cells treated with doxorubicin $230 \mathrm{nM}$, (D) $95 \mu \mathrm{M}$ hesperetin, and (E) combination doxorubicine $230 \mathrm{nM}$ and hesperetin $95 \mu \mathrm{M}$. Pgp expression located in cell membrane showed brown color (red arrow).

increase MCF-7/DOX cells' sensitivity to doxorubicin with $\mathrm{IC}_{50}$ values lower than that is on MCF-7 cells. Hesperetin in combination with doxorubicin is interesting in overcoming the resistance, through its action in inducing apoptosis and suppressing the expression of Pgp.

Hesperetin was able to increase the sensitivity of cells with decreasing $\mathrm{IC}_{50}$ MCF7/DOX to $267 \mu \mathrm{M}$ compared to MCF-7 (more than $500 \mu \mathrm{M}$ ). Increased sensitivity of MCF-7/DOX cells by hesperetin was very interesting to be explored. These results are consistent with several studies that polyphenols, such as flavonol quercetin, increased the sensitivity of cells that are resistant to daunorubicin (Borska et al., 2010). Several other flavonoids such as silymarine biokanine A and Multiple Drug Resistance were able to reverse the function of P-gp inhibition (Chung et al., 2005).
The combination of doxorubicinhesperetin on MCF-7/DOX cells showed that hesperetin was able to increase the cytotoxic effects of doxorubicin. In previous research conducted by Hermawan et al., (2010), hesperidin (glycoside form of hesperetin) showed cytotoxic effects on some cancer cells. Greatest cytotoxic effect was obtained at 200 $\mathrm{nM}$ of doxorubicin and $100 \mu \mathrm{M}$ of hesperidin. In this study, the combination of hesperetindoxorubicin concentration of $95 \mu \mathrm{M}$ and 230nM showed optimum concentration. This data suggest that both hesperitin and hesperidin showed a similar profile.

The combination of hesperetin and doxorubicin based on double staining method caused cells to form apoptotic bodies, which means that hesperetin is possible to increase the cytotoxic effects of doxorubicin via apoptosis. Combination of the two showed increased incidence of apoptosis compared 
with the single treatment. Increased apoptosis also occurs in other citrus flavonoids, such as naringenin-doxorubicin combination on T47D cells observed by Junedi et al., (2010) and on MCF-7 cells observed by Fitriasari et al., (2010). These results strengthen the evidence that hesperetin is a potential candidate in enhancing the cytotoxic effects of doxorubicin through the induction of apoptosis.

Level of doxorubicin at $200 \mathrm{nM}$ did not cause suppression of $\mathrm{Bcl}-2$ expression in $\mathrm{MCF}$ 7 (Meiyanto et al., 2009). Increased apoptosis induction of doxorubicin by hesperetin is likely caused by suppression of $\mathrm{Bcl}-2$ and increased expression of p53. $100 \mu \mathrm{Mm}$ of hesperidin has been proven to suppress the expression of $\mathrm{Bcl}$ 2 in colon cancer cells (Park et al., 2008). Therefore, it is possible that hesperetin's ability to improve apoptosis induction by doxorubicin on MCF-7 cells is mediated by the suppression of Bcl-2 expression. Besides, the mechanism of apoptosis induction may also occur through the increasing expression of p53 as a transcription factor that would increase the expression of Bax. Li et al., (2007) stated that 200nM doxorubicin increased Bax expression in MCF7 cells. But this needs further investigation.

Pharmacological effects of a compound affect the molecular changes in cells. Increased sensitivity of MCF-7/DOX cells to doxorubicin by hesperetin is associated with marker proteins. A protein closely related to drug resistance is P-glycoprotein. P-glycoprotein is a glycoprotein that is responsible for drug, carcinogens, toxins, and other xenobiotics efflux out of the cell in various organs (Bansal et al., 2009).

Doxorubicin treatment increased the expression of P-gp in MCF-7/DOX cells significantly compared with the control cells. Hesperetin and doxorubicin treatment on MCF-7/DOX cells results in a decrease of P-gp on the cell membrane compared with the cells treated with doxorubicin alone. This phenomenon demonstrates the ability of hesperetin in modulating P-gp expression. This fact is in line with the exploration that some flavonoids such as quercetin modulate the expression of P-gp and biokanin A (Chung et al., 2005).
The overall results showed that the combination of doxorubicin and hesperetin has a favorable outlook for breast cancer therapy. With hesperetin, the effectiveness of therapy can be optimized to increase the sensitivity, induce the apoptosis, and suppress P-gp expression. Hesperetin can be developed as a co-chemotherapy agent for doxorubicin and need to be further studied to reveal its molecular mechanisms, so that further application of the combination of doxorubicinhesperetin would be optimum.

\section{CONCLUSIONS}

Hesperetin has cytotoxic effect on MCF$7 /$ DOX cells with $\mathrm{IC}_{50}$ of $95 \mu \mathrm{M}$ and increases the apoptotic induction when combined with doxorubicin. Co-chemotherapy application of doxorubicin and hesperetin on MCF-7/DOX cells showed synergism effect through suppression of P-gp expression.

\section{ACKNOWLEDGMENT}

We express our gratitude to Hibah Kerjasama Luar Negeri dan Publikasi Internasional 2012 Direktorat Jenderal Pendidikan Tinggi, Departemen Pendidikan Nasional, No.: 180/SP2H/PL/ Dit.litabmas/IV/2012 for yhe fundise and supporting this study.

\section{REFERENCES}

Bansal T., Jaggi M., Khar RK., Talegaonkar S. 2009. Emerging Significance of Flavonoids as P-Glycoprotein Inhibitors in Cancer Chemotherapy. I Pharm Pharmaceut Sci, 12(1), 46-78.

Berman HM., Westbrook J., Feng Z., Gilliland G., Bhat TN., Weissig H., Shindyalov IN., Bourne PE. 2000. The Protein Data Bank. Nucleic Acids Res, 28(1), 235 - 42.

Borska S., Sopel M., Chmielewska M., Zabel M., Dziegiel P. 2010. Quercetin as A Potential Modulator of P-glycoprotein Expression and Function in Cells of Human Pancreatic Carcinoma Line Resistant to Daunorubicin. Molecules, 15(2), $857-70$.

Chai S., To KKW., Lin G. 2010. Circumvention of Multi-drug Resistance of Cancer Cells by Chinese Herbal Medicines. Chin Med, 5:26. 
Chung SY., Sung MK., Kim NH., Jang JO., Go EJ., Jeong LH. 2005. Inhibition of PGlycoprotein by Natural Products in Human Breast Cancer Cells. Arch Pharm Res, 28(7), 823 - 828.

Emami A., Zeinali S., Motahari Z., Azizi E. 2005. Resistance to Adriamycin Alters the MDR1/P-gp, Topoisomerase IIalpha Gene and Protein Expression Levels in T47D Human Breast Cancer Cells, Conference Module of 2005 AAPS Annual Meeting and Exposition, downloaded from: www.aapsj.orgabstract AM_2005AAPS2005-001197.pdf, on 2 April 2012.

Gilmore TD., 2006, Introduction to NF-xB: Players, Pathways, Perspectives. Oncogene, 25, $6680-6684$.

Hadjeri M., Barbier M., Ronot X., Mariotte AM., Boumendjel A., Boutonnat J. 2003. Modulation of P-Glycoprotein-Mediated Multidrug Resistance by Flavonoid Derivatives and Analogues. I Med Chem, 46, 2125-31.

Hermawan A., Meiyanto E., Susidarti RA. 2010. Hesperidin Meningkatkan Aktivitas Sitotoksik Doxorubicin pada Sel MCF-7. Majalah Farmasi Indonesia, 21(1), 8 - 17.

Ikegawa T., Ohtani H., Koyabu N., Juichi M., Iwase Y., Ito C., Furukawa H., Naito M., Tsuruo T., Sawada Y. 2002. Inhibition of P-glycoprotein by Flavonoid Derivatives in Adriamycin Resistant Human Myelogenous Leukemia (K562/ADM) Cell. Cancer Lett, 177, 89 - 93.

Khantamat O., Chaiwangyen W., Limtrakul P. 2004. Screening of Flavonoids for Their Potential Inhibitory Effect on Pglycoprotein Activity in Human Servical Carcinoma KB Cell. Chiang Mai Med Bull, 43(2), $45-56$.

Kumar UN., Sailendra M., Peddanna K., Prasad ME., Deepika G., Seshapani P., Latha SL., Jayasimha DR. (2011).Virtual Screening of Flavonoid as Inhibitory Agents of P-Glycoprotein. IJ ABPT, 2(3), $130-140$.

Lentini A., Forni C., Provenzano B., Beninati S. 2007. Enhancement of Transglutaminase
Activity and Polyamine Depletion in B16-F10 Melanoma Cells by Flavonoids Naringenin and Hesperitin Correlate to Reduction of the In vivo Metastatic Potential. Amino Acids 2, 32(1), 95 - 100.

Li X., Lu Y., Liang K., Liu B., Fan Z. 2005. Differential Responses to DoxorubicinInduced Phosphorylation and Activation of Akt in Human Breast Cancer Cells. Breast Cancer Res, 7(5), R589-R597.

Meiyanto E., Hermawan A., Anindyajati, 2012. Natural Products for Cancer-Targeted Therapy: Citrus Flavonoids as Potent Chemopreventive Agents. Asian Pac. J. Cancer Prev., 13(2), 427-436.

Putri DDP., Sarmoko, Febriansah R., Puspitasari E., Ismiyati N., Fitriasari A. 2012. MCF-7 Resistant Doxorubicin are Characterized by Lamellipodia, Strong Adhesion on Substrate and Pgp Overexpression. Indo J Can Chemoprev, 2(3), 304-308.

Ugocsai K., Varga A., Molnar P., Antus S., Molnar J. 2005. Effects of Selected Flavonoids and Carotenoids on Drug Accumulation and Apoptosis Induction in Multidrug-resistant Colon Cancer Cells Expressing MDR1/LRP. In Vivo, $19,433-438$.

Ullah MF. 2008. Cancer Multidrug Resistance (MDR): A Major Impediment to Effective Chemotherapy. Asian Pacific J Cancer Prev, 9, 1 - 6.

Wang S., Kotamraju S., Konorev E., Kalivendi S., Joseph J., Kalyanamaran B., 2002, Activation of Nuclear Factor-kB during Doxorubicin-induced Apoptosis in Endothelial Cells and Myocytes is Proapoptotic: the Role of Hydrogen Peroxide, Biochem. J., 367: 729 - 740.

Wong HL., Bendayan R., Rauth AM., Xue HY., Babakhanian K., Wu XY. 2006. A Mechanistic Study of Enhanced Doxorubicin Uptake and Retention in Multidrug Resistant Breast Cancer Cells Using a Polymer-Lipid Hybrid Nanoparticle System. I Pharmacol Exp Ther, 317(3), $1372-1381$. 